\title{
Erratum to: Carbon mineralization in saline soils as affected by residue composition and water potential
}

\author{
Raj Setia $\cdot$ Petra Marschner
}

Published online: 3 April 2013

(C) Springer-Verlag Berlin Heidelberg 2013

Erratum to: Biol Fertil Soils

DOI 10.1007/s00374-012-0698-x

The original version of this article inadvertently contained a mistake.

The unit of chloroform labile $\mathrm{C}$ in Table 3 is $\mathrm{mg} \mathrm{kg}^{-1}$ soil. 